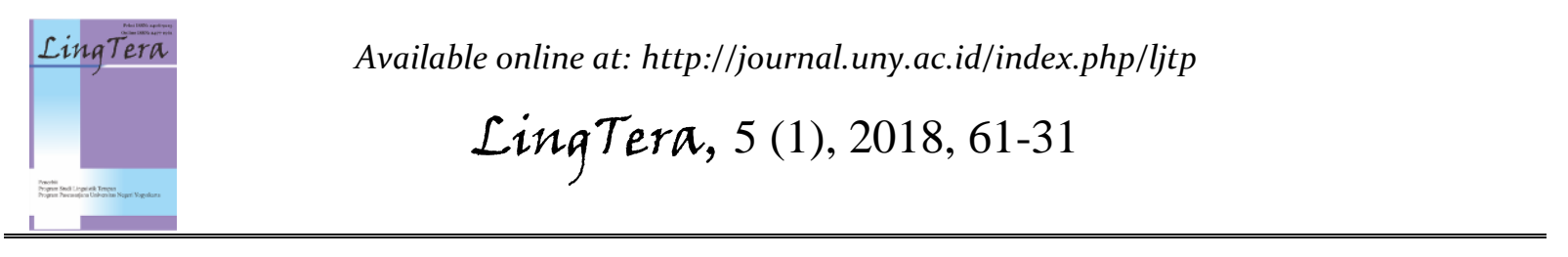

\title{
Innovation in the classroom: Engaging English as a foreign learning students using project-based learning
}

\author{
Alif Karyawati $^{1}$, A. Ashadi ${ }^{2}$ \\ ${ }^{1}$ Institut Agama Islam Negeri Salatiga. Jalan Lingkar Salatiga Km. 2, Kota Salatiga, 50716, Indonesia \\ ${ }^{2}$ Department of English Education, Universitas Negeri Yogyakarta. Jalan Colombo No. 1, \\ Karangmalang, Yogyakarta, 55281, Indonesia \\ * Corresponding Author. Email: alifkarya90@gmail.com \\ Received: 27 November 2017; Revision: 6 September 2018; Accepted: 17 September 2018
}

\begin{abstract}
Project-based learning (PBL) is an instructional approach that focuses on student centre learning, learning process, and students' autonomy. This study was conducted at International Class Program in one of universities in Salatiga. Furthermore, this study explained the teaching strategies by using project based learning in English drama class. The researchers used a case study as the design and collected the data by using interview and observation. The participants of this study were an English drama lecturer and 20 students of International Class Program (ICP). The findings indicate that ICP students dominated the class especially to improve their speaking skill and the lecturer provided new learning atmosphere in teaching English by giving some activities which contains communication, critical thinking, collaboration, and creativity or 4 Cs skills.
\end{abstract}

Keywords: project based learning, English language teaching, 4Cs skills.

How to Cite: Karyawati, A., \& Ashadi, A. (2018). Innovation in the classroom: Engaging English as a foreign learning students using project-based learning. LingTera, 5(1), 61-67. doi:http://dx.doi.org/10.21831/lt.v5i1.17067

http://dx.doi.org/10.21831/lt.v5i1.17067

\section{INTRODUCTION}

With the variety of challenges and opportunities especially in education world,teachers should be creative and innovative in teaching process because students today are called generation $\mathrm{Z}$ which need different teaching method in this era (McKenzie, 2016).Trilling and Fadel (2012, p.7) argue that after graduating from schools students lack some skills such as oral and written communication, critical thinking and problem solving, professionalism and work ethic, teamwork and collaboration, technology applications, and leadership as well as project management. Additionally, Fandiño (2013) believed that in EFL classrooms, teachers should provide practices and processes in learning activities that focuses on several skills namely creativity, critical thinking, collaboration, media literacy, initiative and self-direction, and social and crosscultural skills. According to Cator (2010) to make students succeed in 21 st century, lecturers should provide the strategies how to prepare students' career in the future by improving their critical thinking and interpersonal communication skills.
Moreover, according to Partnership of $21^{\text {st }}$ Century Learning or P21 (2015,p.9) those skills are included in $21^{\text {st }}$ century skills.

Therefore, to help students in mastering their 4Cs skills, the teachers should integrate thesein the teaching and learning activities. Furthermore, teachers need an appropriate learning model to integrate 4Cs skills in English learning and teaching process. Setiadi (2011), one of the challenges faced by English teacher in Indonesia is the lack of communicative activities in the teaching and learning process. Teachers always emphasize on grammar by implementing GTM (grammar translation method). He also added that English teachers have to change their conventional teaching method and it is better to emphasize on communicative activities. Similarity, according to Sotlikova and Sugirin (2016) by building communication activities, it can encourage the students to interact with each other. One of learning models that can be used for this activity is Project-Based Learning (PBL). Bender (2012, p. 7) defines that PBL is a learning model which improves students' learning knowledges, skills, and societyby using projects 
such as product in form of real-world research and question. Bell (2010) argues that by using standardized test many of $21^{\text {st }}$ century skills were not measurable. However, teacher can make an authentic assessment by using PBL. Therefore, students can learn from their processes of learning. Ravitz, Hixson, English, and Mergendoller (2012,p.1) state that project based learning will give the impact for students if used by a professional teacher who expert in project based learning. From this opinion, teachers can use PBL for teaching English; especially for productive language skills, namely writing and speaking skills. By using PBL students are able to response complex questions, problems, or challenges and to master the $21^{\text {st }}$ century skills, especially 4Cs skills.

With regards to the explanations above, the researchers investigated which had some programs to prepare the students in facing globalization era. One of the programs was the opening of International Class Program (ICP). Based on the previous observation, the researcher found an interesting student support programs in International Class Program namely bilingual drama performance which is shown in Art and Language Exhibition (ALE) in semester 4. ICP provided English and Arabic drama classes in curriculum to train the students in improving their 4Cs skills and language skills. These drama classes conducted twice in semester 1 and semester 2. This drama takes folklore as a title of story and Javanese puppet or wayang wong as a theme. Moreover, the students not only performed the drama but also showed traditional dance. Through this activity the students were able to explain Indonesian culture to the foreigners from other countries. In this case, the researchers only focused on English drama class in International Class Program. From previous observation, the researchers found that the lecturer of English drama class teaches the students by using Project Based Learning (PBL) which 4Cs skills were included in each step of this method in teaching and learning process.

In this case, the researchers was interested in whatinstructional strategies used by the lecturer to teach 4Cs skills in English drama class and what opportunities and challenges in developing 4Cs skills through PBL in the English drama class. Based on the background of the study, the researchers identified this problem namely: (1) How does the lecturer teach 4Cs skills by using project based learning in the English drama class?; (2) What are the opportunities and challenges of PBL in developing 4Cs skills in the English drama class?

\section{$21^{\text {st }}$ Century Skills}

P21 (2015, p.1) states that there are 19 skills in $21^{\text {st }}$ century skills which each of it needs a knowledge development and understanding for students. The 19 skills of $21^{\text {st }}$ century skills are divided into three groups. P21 (2015, p.1) states that there are 19 skills in 21 st century skills,each of which needs a knowledge development and understanding for students. The 19 skills of $21 \mathrm{st}$ century skills are divided into three groups. The first group is learning and innovation that consist of creativity and innovation, critical thinking and problem solving, communication, and collaboration. The second group is information and technology that consist of information literacy, media literacy, and ICT literacy. The last group is life and career that consist of flexibility and adaptability, initiative and self-direction, and social and cross-cultural skills, productivity and accountability, and leadership and responsibility.

From these 19 skills, there are four essential skills namely critical thinking, problem solving, communication and collaboration or $4 \mathrm{Cs}$ skills that should be mastered by students (P21, 2010 \&American Management Association, 2010). Wallwork (2015) agrees that in education 4Cs skills are touted as a soft skill key for students to be competitive and competent in finding job by emphasizing collaboration, creativity, critical thinking and communication skills.

\section{Project-Based Learning}

Project-based learning is a learning model to engage students, teachers, and curriculum. Then, students can do their assignment personally or in group to achieve the standard (Harrigan, 2014, p. 26). Bell (2010, p. 39) argues project based learning is a learning approach that gives important strategies for students to success in the $21^{\text {st }}$ century. She also argues that by using project based learning students can learn from their processes of learning. Fandiño (2013) argues that in EFL classrooms, teacher should provide practices and processes in learning activities that focuses on several skills namely creativity, critical thinking, collaboration, media literacy, initiative and self-direction, and social and cross-cultural skills. A recent study indicates that there are some benefits in using ProjectBased Learning in the classroom. Sumarni (2015, p. 480) states that PBL can improve students' 
collaboration, communication, creativity, and problem solving skills. There are several positive impacts of using PBL in the classroom. Dewi (2014) argues that PBL activities in the classroom make the student fun and enjoy and also the use of students' project that is relevant to the real world will reinforce students' knowledge. She also adds that to make PBL activities successful in the classroom, the teacher should minimize stiff and formal relationship between the teacher and students. On the contrary, there are some experts find some challenges of PBL. This learning method requires much time because students have to solve the problem. It will give the impact to time allocation for the subject (Grant, 2002, \& Lasauskiene \& Rauduvaite, 2015, p. 790). Morover, Sumarni (2015, p. 482) argues that there are several equipments that should be prepared in conducting PBL, therefore the electricity should be increased.

Edutopia (2007) provides six steps of Project Based Learning in teaching and learning process by starting with the essential question, designing a plan for the project, creating schedule, monitoring the students and the progress of the project, assessing the outcome, and evaluating the experience. In addition, according to Larmer (2013) in conducting PBL activities to improve students' 4 Cs skills, the lecturer should pay attention to these three aspects namely design, develop, and determine.

The first aspect is design which lecturer can drive the students to promote their critical thinking by using questions for their project, design the process of project that emphasizes critical thinking skill, give the reasons to students why they should work collaboratively, find the ways how to interact with the experts and communicate with them for students, and promote students' creativity and innovation skills by using project that engage design and invention, challenges, problem-solving tasks, and arts integration.

In develop aspect; lecturer should build students' skills in making the project by explaining the characteristics of each 4Cs skill. Lecturer can ask the students to do the project in real-life like how people think critically, work together, communicate with audience and use creativity to create some products, teach the students how to solve the problem and evaluate the information to answer a question, arrange the project teams with strategy, shared leadership experience, manage team building activities, set up norms for collaboration, and lead the students to make decisions in their team, strengthen the students' active speaking and listening, promote the culture in the classroom by building students' creativity skill, help English learners to think carefully about language functions in the $21 \mathrm{st}$ century learning activities.

\section{Determine}

Furthermore, lecturer should determine the results of the project by assessing students' 4Cs skills by providing rubrics that describe each of the 4Cs skills, asking the students to keep the journal of the project to record their 4Cs skills, helping the students to reflect their progress in improving 4Cs skills at the end of the project, and putting 4Cs skills into project grading system.

\section{METHODS}

A descriptive qualitative research design in the form of case study was selected to describe the implementation of 4Cs skills in the research site and to explain the university readiness to support students' 4Cs skills and English ability. Yin $(2003$, p.1) argued case study is the most appropriate technique when the event has been little controlled by the researchers that focuses on phenomenon in the real life to answer "how" or "why" questions. Similarity based on the previous explanation this study was arranged to answer how the lecturer teach 4Cs skills by using project based learning in the English drama class and explain the opportunities and challenges of PBL in developing 4Cs skills in the English drama class.

The research took the setting in a private university from 6 February to 19 March 2016. The participants of this study were an English drama lecturer and 20 4th semester students of International Class Program that consisted of 8 students from English education program, 7 students from Islamic education program, and 5 students from Arabic education program. For the detail information of ICP students, there were 12 female students and 8 male students and the students' age around 20-22 years old.

The researchers spent 7 days to initially observe the classroom activities on 6 February19 March 2016 when the students were in semester 2. The researchers did this observation by monitoring the lecturer and the students in teaching and learning process by using reflective notes. According to Bogdan and Biklen (2003), this reflection in observation sheet is to improve the notes in the research field. Moreover, to keep 


\section{LingTera, 5 (1), 2018 - 64 \\ Alif Karyawati, A. Ashadi}

the privacy, the teaching and learning process was not recorded during the observation session.

The interview was conducted in face-toface meeting with structured questions. The English drama lecturer and 20 ICP students were the respondents of this instrument. The first interview was conducted on $3^{\text {rd }}$ March 2017. There were two sessions in the second interview which 20 ICP students were the respondents of this second interview. The first session was conducted on 29th April 2017 and the second session on 30th April 2017 which 10 students became the interviewees for each session.

Data analysis consists of four kinds of activities based on Miles and Huberman's view (2014:8). The first activity is data collection. The researchers collected the data by observing the teaching and learning process in English drama class. Afterwards, the researchers interviewed 20 ICP students and English drama lecturer with structured interview questions. The second activity is data condensation by selecting and simplifying the data that taken from interview, observation, and documentation. In this step, the irrelevant data was deleted and the needed data was included in this study to avoid the data occurring repeatedly. Subsequently, the researchers used data display. It helped this study what is happening and to do further analysis or action based on understanding in the form of interview transcription and vignettes. The last activity is conclusion drawing or verification. From the beginning of data collection, the qualitative analyst is starting to decide what things mean-is noting regularities, patterns, explanations, possible configurations and propositions. The researchers found the answer related to instructional strategies in teaching $4 \mathrm{Cs}$ skills through PBL in the English drama class, the opportunities and challenges in developing 4Cs skills through PBL, and the students' reaction after participating in the English drama class. After that, the results of this step were examined for reliability and validity through triangulation to check the data from different data collection techniques to make a final conclusion. Finally, the results of these data analyses were connected in the sentences through a descriptive qualitative. This method used to explain the analysis along with some theories and some parts of analysis interpretation.

\section{FINDING AND DISCUSSION}

\section{Efforts in Teaching 4Cs Skills through the English Drama Class}

Related to the teaching and learning process in the classroom, there were six steps in the PBL namely (1) starting with the essential question, (2) designing a plan for the project, (3) creating schedules, (4) monitoring the students and the progress of the project, (5) assessing the outcome, and (6) evaluating the experience (Edutopia, 2007). The researchers used observation to strengthen the results of the lecturer interview. The detail information of the implementation of 4Cs skills by using project based learning in English drama class were explained as follows:

Starting with the Essential Question

Mrs. WL as lecturer asked the students to watch English drama video. After that, she divided the students into four groups which contained five students for each group and asked them to criticize the strengths and the weaknesses of the drama video in the discussion session. In this activity the lecturer led the students to think critically by asking some questions such as "what do you think of this video? What about the decoration, why? What is your opinion? How to make a good English drama?"

Designing a Plan for the Project

In this step, Mrs.WL asked the students to arrange the drama project. In this activity, the lecturer asked the students to discuss about plot, scene, and character for their drama.

\section{Creating Schedule}

Mrs.WL asked the students to arrange the three activities. The first activity was preproduction to arrange all of things that should be prepared before performance such as script and cast. The second activity was production; it meant time for the students to perform their drama. The last activity was post-production to evaluate students' performance. Moreover, the project schedule is mentioned in Table 1.

Table 1. Project Schedule

\begin{tabular}{cll}
\hline No. & Schedules & Activities \\
\hline 1. & Pre-production & Script and Cast \\
2. & Production & Performance \\
3. & Post-production & Evaluation \\
\hline
\end{tabular}


Monitoring the Students

In the pre-production, Mrs.WL focused on the students' drama script and cast. Here, Mrs.WL as facilitator walked around the groups and asked them about their problems in writing the drama script. Mrs. WL opened the opportunity to the students if they had questions related to the drama script and cast.

Assessing the Outcome

The students were performing their drama and Mrs. WL assessed the students' work. The lecturer also asked the students to give some comments for their classmates' performance. Table 2 shows how the lecturer assessed her students.

Table 2. Students' Performance Rubric

\begin{tabular}{llllll}
\hline \multicolumn{1}{c}{ Criteria } & 25 & 20 & 15 & 10 & 5 \\
\hline Loud and clear voice & & & & & \\
Accuracy, fluency, and & & & & & \\
intonation & & & & & \\
Body language \\
Group collaboration \\
*25: excellent, 20: good, 15: Average, 10: below \\
average, 5: poor.
\end{tabular}

Evaluating the Experience

In the last steps of project based learning, Mrs.WL asked the students to give their opinion about their' drama performance. They discussed about their weaknesses and strengths in performing the drama.

\section{The Opportunities and Challenges of PBL in Developing 4Cs Skills in the English Drama Class}

From the above explanation, the students learned through many activities which consisted of $4 \mathrm{Cs}$ skills in the classroom to arrange their project. These are the summary of teaching and learning activities which consist of 4Cs skills:

The results of interviews revealed that most students agreed that the activities in this course gave positive impacts for their critical thinking skill. It started from planning, organizing, controlling, and etc in preparing the drama. In arranging the script and dialogue, they should consider the correctness and accuracy in using English language because they will perform the drama not only in front of the regular students and their lecturers but also the foreigners as guests Therefore, they should be critical thinker to offer an amazing drama performance. The lecturer reported the strength of PBL to improve students' critical thinking in her classroom was in using questions in the first step of project based learning. Through this activity, it can improve students' critical thinking and drive the students to speak dominantly in the classroom. However, she also reported the problems in improving students' critical thinking skill. She said that she had tried to ask questions to students but only active students answered her questions. However, she still gave the opportunity to passive students to share their opinions.

In improving communication skill most students agreed that English drama class provided them the activities containing communication skill. In the discussion session the students learned to respect each other's opinion and in the practice session the students can improve their English communication skill. However, the use of discussion session and group assignment made the active students had more proportions in speaking than others. Again, to solve this problem the lecturer gave the opportunity to passive students to express their opinions.

For collaboration skill, most students agreed that teamwork in group assignment in this class can improve students' collaboration skill whereas some students reported that the clumsiness made her collaboration skill did not develop well and by using group assignment not all students take a part in finishing their assignment some students just rely on one student. Therefore, the lecturer should pay attention to all students to improve students' confidence so that the students can collaborate and cooperate with each other. The use of group assignment made the students learn the meaning of teamwork; therefore it helped the students improve their collaboration skill.

All the students agreed that English drama class provided creativity skill activities. Those activities in the classroom were writing the story, decorating the auditorium, and designing the wardrobe for drama. However, according the lecturer, she found that the obstacle of PBL by using group assignment made only certain students can improve their creativity skill. She also reported that students' creativity appeared during the preparation of ALE drama performance. Moreover, for students' creativity skill in the classroom it can be seen when they arrange the storyline.

In these activities the students tried to solve the problem together in arranging the drama (Willingham, 2007). The students also can learn to give the reason logically in order to not be 
manipulated with other arguments (Brookfield, 2012). Moreover, the activity which contains communication skill is in the interaction between student and student or lecturer and student in the classroom (Keyton, 2011). The students' project was conducted in group; therefore each student has his or her own responsibility, this activity contains collaboration skill which all students help each other to finish their project (Lai, 2011). Not only active students but also passive students can play an active role in learning process. Moreover, in making the project the students also cooperate with some experts (Larmer, 2013). It also helped the students in improving their collaboration skill in the real life. Whereas, in designing the drama the students were demanded to make a good drama. Therefore, it drives students' creativity skill to arrange their project in order to be more creative, innovative, and interesting (Beghetto, 2005).

\section{CONCLUSION}

There are two points that can be concluded in this study. Based on the findings and discussions above, the lecturer taught the class by starting with the essential question to improve students' critical thinking skills. The lecturer also participated in designing plan and creating the schedule of the project to develop students' communication and collaboration skills. Moreover, to develop students' creativity skill, the lecturer monitored the students' project by giving some feedbacks for them and it can be seen from their drama performance.

The second point is the opportunity and the challenge of PBL to develop 4Cs skills in the English drama class. The opportunity is by using projects in this class students can develop their critical thinking, communication, collaboration, and creativity skills. It can be seen from the activities when the students designing, preparing, and performing the projects. Moreover, the challenge of PBL to develop 4Cs skills in the English drama class is the use of group assignment to arrange the project just gives the opportunity for active students. Therefore, the lecturer should consider between students' individual and group assignment.

\section{REFERENCES}

American Management Association. (2010). AMA 2010 critical skills survey. Executive Summary. Retrieved October, 25, 2010.

Bell, S. (2010). Project-based learning for the 21st century: Skills for the future. The
Clearing House, 83(2), 39-43. http://doi.org/10.1080/000986509035054 15

Bender, W. N. (2012). Project-based learning: Differentiating instruction for the 21st century. Corwin Press.

Edutopia. (2007). How does project-based learning work?Tools for understanding the process of planning and building projects. Accesed February 022016. Retrieved from:https://www.edutopia.org/projectbased-learning-guide-implementation

Fandiño, Y. J. (2013). 21st century skills and the English foreign language classroom: A call for more awareness in Colombia. Gist Education and Learning Research Journal, 7, 190-208. Accessed on September 072016 Retrieved from http://gisteducation.weebly.com/uploads/7 /9/2/8/7928165/21st_century_skills_and_t he_english_foreign_language_classroom_ yamith_jos_fandio_colombia.pdf

Fragoulis, I. (2009). Project-based learning in the teaching of English as a foreign language in Greek Primary Schools : From Theory to practice. English Language Teaching, 2, 113-119.

Grant, M.M. (2002). Getting a grip on PBL: theory, cases and recommendations. Meridian: A Middle School Computer Technologies Journal A Service of NC State University, Raleigh, 5(1). Accessed on December 21 2016. Retrieved from http://www.ncsu.edu/meridian/win2002/5 14/project-based.pdf.

Harrigan, G. (2014). A case study of teachers' and administrators' experiences integrating project-based learning. (Unpublished doctoral dissertation). Walden University. Accessed on January 04 2017. Retrieved from:

http://scholarworks.waldenu.edu/dissertati ons $/ 530 /$

Larmer, J. (2013). Driving question: Is there a best way to develop the 4Cs in all students? Partnership for $21^{\text {st }}$ century learning (P21). Accessed on April 01 2016. Retrieved from: http;//www.p21.org/newsevents/p21blog/1249-is-there-a-best-wayto-develop-the-4cs-in-all-students.

Lasauskiene, J., \& Rauduvaite, A. (2015). Project-based learning at university 
Alif Karyawati, A. Ashadi

teaching experiences of lecturers. Procedia - Social and Behavioral Sciences .Vol.197 p.788-792. Accessed on January $042017 . \quad$ Retrieved from: http://www.sciencedirect.com/science/arti cle/pii/S187704281504183X

Miles, M.B., Huberman, A.M., \& Saldana, J. (2014). Qualitative data analysis a methods sourcebook. Thousand Oaks, CA: Sage Publication, $3^{\text {rd }}$ edition.

Partnership of $21^{\text {st }}$ Century Learning (P21). (2015). P21 framework definitions. Accessed on August 13 2016. Retrieved from:

http://www.p21.org/storage/documents/do cs/P21_Framework_Definitions_New_Lo go_2015.pdf.

Punch, K.F. (2009). Introduction to research methods in education. London: SAGE Publication.

Ravitz, J., Hixson, N., English, M., \& Mergendoller, J. (2012). Using project based learning to teach 21 st century skills: Findings from a statewide initiative. Paper presented at Annual Meetings of The American Educational Research Association.

Rich, E. (2010). How do you define 21 st-century learning. Education Week, 4(1), 32-35.

Setiadi, B. (2011). Challenges and improvement of teaching learning process in high schools. Presented at Bandar Lampung University. Accessed on January 202016.Retrieved from: http://www.ubl.ac.id/news-a-article/1361seminar-fkip.html

Sotlikova, R., \& Sugirin, S. (2016). Teachers' perceptions on using communicative language teaching in the English class. LingTera, 3(2), 203-209. doi:http://dx.doi.org/10.21831/lt.v3i2.111 37

Sumarni, W. (2015). The strengths and weaknesses of the implementation of project-based learning. International Journal of Science and Research (IJSR) ISSN (Online): 2319-7064, 4(3), 478-484.

Trilling, B., \& Fadel, C. (2012). 21st century skills: Learning for life in our times (first). USA: Jossey-Bass.

Wallwork, C. (2015). Reframing the 4 Cs: 21st Century Mindsets. Accesed on January 02 2016.Retrieved

from:http://eddesignlab.org/2015/03/21stcentury-mindsets/ 